bacteria "which do not exchange information naturally" and between bacteria and eukaryotic organisms "which cannot naturally occur"'.

The patent says that the techniques can be used with genes to form other bacterial cells, mammalian cells, plant cells and so on. The cloning of multiple genes is mentioned and the production of multiple copies of peptide hormones said to be of especial importance in the cases of parathyroid hormone, growth hormone, gonadotropin, insulin, ACTH, somatostatin and prolactin. Other useful products of genetic manipulation listed

\section{Europe waits to see}

European pharmaceutical companies have reacted cautiously to the announcement by Stanford University that licences on the Boyer-Cohen patent are now for sale. But many of them are huddled with their patent lawyers.

Under the terms of US patent law, companies outside the United States will be obliged to apply for licences only if they intend to market within the United States products made with techniques covered by the patent. Because most European companies are anxious not to foreclose future markets, however, they face the same dilemma as US companies in deciding whether to pay the licence fee and subsequent royalties.

Most companies this week were unwilling to guess what they may in the end decide to do, although it seems that some of them have already been consulted (through their American subsidiaries) by Stanford. Some point out that Stanford's advertised terms are reasonable, but also say that the university has been well advised in fixing a low fee and royalty rate for a non-exclusive licence to exploit a patent as general as Boyer-Cohen. Larger proprietary costs will accrue, they say, when the time comes to buy an exclusive licence to use a more specialized technique from one of the companies set up in the past few years to carry out research and development in genetic engineering.

Some legal anomalies stand out. Will, for example, a European manufacturer that seeks to market in the United States a product made by a process developed by a non-American genetic engineering company itself be required to pay a royalty, or will the legal obligation fall on the company that carried out the research and development?

In the circumstances, three options are being considered: to ignore the licence and face Stanford when products are placed on the US market; to challenge the patent; or simply to pay up. European companies, however, are unlikely to initiate direct challenges, preferring to wait and see what happens in the United States.

Judy Redfearn include serum proteins, ferritin, myoglobin, interferin (sic), kinins and transcortin.

While illustrating the claims made with specific examples, the patent says that "it is obvious that certain changes and modifications may be practised" within its scope. Among the specific claims are for the ligation both of blunt-ended and "staggered" DNA molecules, to form recombinant plasmids.

On the face of things, the patent would seem not to cover the use of vehicles other than plasmids for the cloning of DNA, so that techniques of genetic manipulation involving the use of animal virus grown on susceptible cells in tissue culture would seem not to be protected. Nor is the development of cloning vectors able to switch between eukaryotic and prokaryotic cells. Yeasts are, however, mentioned.

The patent makes no claim to protection for organisms or plasmids with particular properties, presumably because it was not known whether organisms could be patented until the Supreme Court decided earlier this year in favour of a patent application on behalf of $\mathrm{Dr}$ A.M. Chakrabarty by the General Electric Company for a strain of Pseudomonas designed for digesting oil spills. Stanford is apparently waiting to hear whether its applications for protection for specific bacterial cloning strains will be successful

\section{Soviet biotechnology}

\section{Further resolve}

Soviet progress in biotechnology is being hampered by shortages of reagents and apparatus, and delays in the construction of new facilities. Experiments are limited in scale, and too little is being done to implement theoretical results.

This is the tenor of last month's resolution of the Central Committee of the Party and the Council of Ministers on the further development of biotechnology. The official Soviet commitment to biotechnology began suddenly in May 1974 with a similar resolution, which in effect gave biotechnology priority status and funding from then rather than from the start of the succeeding five-year plan.

Reviewing progress in the past seven years, the Central Committee and Council of Ministers last month noted that the 1974 resolution had introduced "radical changes" in the biological sciences, especially in molecular biology, bioorganic chemistry, molecular genetics and immunology. Research cadres had been trained within a very short time, and in several fields Soviet scientists had attained a "leading position in world science". Despite high hopes, a flourishing biotechnology industry had not materialized.

The resolution suggests, however, that this is not simply because of the difficulty of turning research results into practice. The resolution charges the Academy of
Sciences, the State Committee for Science and Technology, the State Planning Committee (Gosplan) and the governments of the union republics with the task of ensuring the conditions for these results to be introduced in agriculture, medicine and industry. But it also calls for intensified fundamental research both directly within the framework of the Academy of Sciences, and the ministries.

The State Committee for Science and Technology, the Academy of Sciences and Gosplan are to adopt a special targetorientated research programme in biotechnology, which will be coordinated by the State Committee's special council on biotechnology and the academy.

The supply problem remains. The resolution merely says that means of ensuring supplies of equipment, reagents, "biochemical preparations", computer technology and an information base in biology and biotechnology have been " "noted", but makes no suggestion of what form these measures are to take. Vera Rich

\section{US air pollution}

\section{Reagan retreats}

\section{Washington}

Unexpectedly strong opposition has forced the Reagan Administration to retreat from plans to seek sweeping changes in US air pollution legislation. Initially $\mathrm{Mr}$ Reagan had announced his intention to demand a substantial weakening of the Clean Air Act when it comes up for renewal by Congress next month; but following objections not only from environmentalist groups and Democratic congressmen, but also from several leading members of the Republicandominated Senate, the Administration said last week that it was looking for more modest amendments.

One of the most significant shifts in the Administration's position has been its decision to continue to use health standards and "sound scientific data", rather than economic costs, as the basic principle for determining how air pollution should be regulated. Mr Reagan's budget director, Mr David Stockman, as well as members of his Council of Economic Advisors and outside industrial groups, had strongly urged that cost-benefit techniques be added to the statutory requirements of the Clean Air Act, first passed by Congress in 1970.

However, Mrs Anne M. Gorsuch, the new administrator of the Environmental Agency, announced last week that the Administration did not intend to go far down this particular path. Listing the basic principles to be followed in developing legislation to extend the act, she said that "cost-benefit analysis should not be included as statutory criteria in setting these standards", but that standards "should be based on sound scientific data demonstrating where air quality represents 